\title{
Use of endophytic bacteria from roots of Cyperus rotundus for biocontrol of Meloidogyne incognita
}

\author{
MARDHIANA, ANKARDIANSYAH PANDU PRADANA", MUH ADIWENA, DWI SANTOSO, RIZZA WIJAYA, \\ ADITYA MURTILAKSONO \\ Program of Agrotechnology, Faculty of Agriculture, Universitas Borneo Tarakan. J1 Amal Lama No 1, Tarakan 77123, North Kalimantan, \\ Indonesia, `email: pandupradana.id@gmail.com
}

Manuscript received: 4 July 2016. Revision accepted: 20 August 2017.

\begin{abstract}
Mardhiana, Pradana AP, Adiwena M, Santoso D, Wijaya R, Murtilaksono A. 2017. Use of endophytic bacteria from roots of Cyperus rotundus for biocontrol of Meloidogyne incognita. Biodiversitas 18: 1308-1315. Yield loss due to M. incognita infection in tomato plants cultivation can reach $60 \%$. The problem is able to be solved through the application of endophytic bacteria. In this study, endophytic bacteria from root Cyperus rotundus were isolated using Tryptic Soy Agar media. The bacteria isolates were then tested their safety against plants and mammals. The phenotypic and physiological properties of selected isolates were characterized and tested to know their resistance to antibiotics, and their ability in suppressing the infection rate of $M$. incognita on tomato. Eighteen bacterial isolates were obtained and 8 of them are categorized as safe bacteria for plants and mammals, which could be used in further tests. A result of the physiological test showed that bacterial isolates were able to produce protease enzyme (87.5\%), chitinase enzyme $(62.5 \%)$, and $\mathrm{HCN}(37.5 \%)$, having urease activity $(75 \%)$ and could dissolve phosphate (87.5\%). Based on the test results, all endophytic bacteria effectively increased tomato growth and suppressed the severity of $M$. incognita infection with the most stable isolate as a biocontrol agent of $M$. incognita was CRS16.
\end{abstract}

Keywords: Antibiotic resistance, biosafety, lytic enzymes, plant growth

\section{INTRODUCTION}

Root-knot nematodes (RKN, Meloidogyne spp.) are one of plant pest, which has significant negative impact on the tropical area. They can have a wide host range and interact with other pathogens causing the yield loss in some agricultural commodities. Infestation of Meloidogyne spp. can reduce the production up to $40-60 \%$ on tomato, $35 \%$ on potato, and $20 \%$ on bean. Symptoms caused by infestation with $M$. incognita are indicated by gall at the root. The existence of gall can disrupt water and minerals distribution systems from the soil through the roots to all parts of the plant leading to the disruption of new root growth, plant wilting, slow plant growth, stunted growth, and chlorosis (Moens et al. 2009). Meloidogyne spp. Infestations can also increase the severity of the wilt disease caused by Fusarium oxysporum and Ralstonia solanacearum in tomato (Muthamia and Ravichandra 2012).

Researches on chemical, physical and mechanical control of nematodes had been conducted, but the nematodes infestation is still a major problem, which could not be fully resolved. One of efforts to control nematodes is using endophytic bacteria as biocontrol agents. According to Hardoim et al. (2015), endophytic bacteria are bacteria living in plant tissues without causing disease symptoms within the plant and can be isolated from sterilized surface of plant tissue. Action mechanisms of endophytic bacteria as biocontrol agents include the production of antimicrobial compounds, spatial and nutrients competition, micronutrient competition, the production of siderophores, and the induction of plant resistance against pathogen infestation.

Biological control using endophytic bacteria is one of the alternative controls, which can be expected to tackle the issue. The endophytic bacteria were reported to effectively control nematodes in several crops. Endophytic bacteria isolated from potato such as Pseudomonas and Streptomyces species were reported to be able to reduce the population of Meloidogyne incognita (Krechel et al. 2002). Application of endophytic bacteria through seed treatment could reduce $30-50 \%$ galls of $M$. incognita on tomato (Munif et al. 2013). Treatment of P. chlororaphis strain $\mathrm{Sm} 3$ in strawberries could reduce population of root-lesion nematode (Pratylenchus penetrans) by $41-61 \%$ and was able to enhance plant growth (Hackenberg et al. 2000).

The advantages of endophytic bacteria as biocontrol agents are their ability to increase the growth of plants, known as Plant Growth Promoting Bacteria (PGPB), by increasing the availability of nutrients, and also their ability to produce the growth hormone for inducing plant resistance, known as induced systemic resistance (ISR). ISR is an alternative mechanism to control the broadspectrum plant diseases (Pieterse et al. 2014, Chebotar et al. 2015).

The endophytic bacteria were reported to have a broad host specificity. Mekete et al. (2009) have successfully isolated endophytic bacteria from coffee plant to control the root-knot nematodes on tomato. In addition, Mohanty et al. (2017) have also isolated endophytic bacteria from Jatropha curcas to promote the growth of maize. 
Therefore, there are great opportunities to explore the endophytic bacteria from various plants. The species of plant that their endophytic bacterial effectiveness as a biocontrol agent has not been widely reported is Cyperus rotundus. Therefore, this study was aimed to isolate and characterize the most effective endophytic bacteria originated from C. rotundus roots as a biocontrol agent of Meloidogyne incognita on tomato.

\section{MATERIALS AND METHODS}

\section{Study area}

This research has been done in the laboratory and greenhouse experiment at Laboratory of Plant Nematology (Department of Plant Protection), and green house Faculty of Agriculture, Bogor Agricultural University, Bogor, Indonesia.

\section{Isolation of endophytic bacteria}

The endophytic bacteria were isolated from the roots of C. rotundus. Samples were taken around Bogor Agricultural University campus, Indonesia. Roots of plant were taken as much as $1 \mathrm{~g}$, which was then washed using tap running water to remove soil particles. Roots surface were further sterilized using $1 \%$ sodium hypochlorite $(\mathrm{NaOCl})$ solution for 1 minute, $70 \%$ alcohol for 1 minute, and rinsed with sterile distilled water 3 times. Subsequently, the roots were dried using a sterile tissue paper. Samples were further placed on the Tryptic Soy Agar (TSA) media to determine the success of surface sterilization.

Sterile root samples were then macerated using a sterile mortar until smooth with the addition of 1: $10(\mathrm{w} / \mathrm{v})$ distilled water. The suspension was diluted 10 -fold using sterile distilled water. A total of $0.1 \mathrm{~mL} 10^{-3}$ dilution suspension was further spread on $20 \%$ TSA media using sterile microbiology glass beads then incubated at $28^{\circ} \mathrm{C}$ for 72 hours. Single colonies with different colony shape, size, texture, and color were further sub-cultured in respective media (100\% TSA), followed by the incubation for 48 hours.

\section{Hypersensitivity reactions test}

The endophytic bacteria were grown on TSA media using $9 \mathrm{~cm}$ diameter petri dish and incubated for 24 hours. The growing bacteria were then harvested using $2 \mathrm{~mL}$ of sterile distilled water. The suspension was further infiltrated on the leaf blade of tobacco (Kemloko 3 variety) at the bottom and incubated for 48 hours. The occurrence of necrosis on leaves of tobacco plants was observed. Bacteria that did not show necrosis on leaves of tobacco were used for further testing (Klement and Goodman 1967).

\section{Hemolysis activity test}

Endophytic bacteria with no indication of hypersensitivity reaction were used in this test. The bacteria were grown on blood agar media, incubated for 24 hours. The formation of hemolysis zones was observed. $\alpha$ hemolysis toxin produced by endophytic bacteria would form a dark zone, while $\beta$-hemolytic toxin would form a light zone, and $\alpha \beta$-hemolysis toxin will form a zone of light followed by a bit dark around the colony. Bacteria with hemolytic activity were not used in the further test (Tille 2015).

\section{Characterization of phenotypic and physiological properties of endophytic bacteria}

Phenotypic characters of endophytic bacteria colonies

The phenotypic performance of Endophytic bacteria colony was observed based on the shape of the colony, size, texture, color, and elevation.

\section{Gram staining}

Endophytic bacteria Gram staining was conducted using Himedia Gram-stain kit. 24-hour-old bacterial colonies were taken using a needle loop and placed on a slide surface contained a drop of sterile water. The suspension of bacteria on the slide was flattened and passed through the bunsen burner.

Crystal violet was dripped over the preparation of bacteria that had been fixed, left to stand for 1 minute and then washed with distilled water and left for a while. Iodine solution was dripped on the dried preparations, left to stand for 1 minute and washed with $96 \%$ alcohol until the solution flow was not colored. Preparations were washed with distilled water and left for a moment. The next step, dried preparations were dripped with safranin, left to stand for 1 minute and washed again using distilled water. Observations were conducted after preparations were dried, using a light microscope with a magnification of 1000x. Gram-positive bacteria bound the crystal violet after washing with alcohol so that preparations would be dark violet after staining and Gram-negative bacteria did not bind the crystal violet so they would be red after staining (Beveridge 2001).

\section{Proteolytic activity}

Proteolytic activity was tested using skim milk media at $\mathrm{pH}$ 6.5. Media composition consisted of $10 \mathrm{~g}$ of skim milk, $15 \mathrm{~g}$ of TSB, $7.5 \mathrm{~g}$ of agar and $500 \mathrm{~mL}$ of distilled water. Agar, TSB and distilled water were sterilized by autoclaving at $121^{\circ} \mathrm{C}$ for 15 minutes. After sterilization was finished, skim milk was further added when the media was still hot. Bacterial cultures were streaked on the media added to skim milk. Proteolytic activity was indicated by a clear zone around the colonies of bacteria, 48 hours after treatment (Sokol et al. 1979).

\section{Chitinolytic activity}

Test medium used was $1 \%$ chitin, consisted of $15 \mathrm{~g}$ of agar, $5 \mathrm{~g}$ of glucose, $2 \mathrm{~g}$ of peptone, $10 \mathrm{~g}$ of colloidal chitin, $0.5 \mathrm{~g}$ of $\mathrm{K}_{2} \mathrm{HPO}_{4}, 0.5 \mathrm{~g}$ of $\mathrm{MgSO} 4,0.5 \mathrm{~g}$ of $\mathrm{NaCl}$ in $1 \mathrm{~L}$ of distilled water with a $\mathrm{pH}$ of 6.2. Bacterial cultures were streaked onto the surface of the medium and incubated at room temperature for 4 days. Chitinolytic activity was observed with the clear zone around the bacterial streak (Kuddus and Ahmad 2013). 


\section{HCN production}

The medium used to grow the bacteria consisted of 4.4 $\mathrm{g}$ of glycine, $30 \mathrm{~g}$ of TSB, $15 \mathrm{~g}$ of agar in $1 \mathrm{~L}$ of distilled water. The medium was poured into a $9 \mathrm{~cm}$ diameter petri dish. Preparation of cyanide detection solution (CDS) paper was performed using $2 \mathrm{~g}$ of picric acid and $8 \mathrm{~g}$ of sodium carbonate, then dissolved in $200 \mathrm{~mL}$ of sterile distilled water. The solution was used to soak the $1 \times 1 \mathrm{~cm}$ sterilized filter paper. The filter paper was soaked up to bright yellow; then the filter paper was dried in a laminar air flow.

The endophytic bacteria were streaked at test medium. Filter paper which had been dipped in a solution of CDS was attached to the inside of the petri dish lid. The bacteria were incubated for 7 days at room temperature, and then on the 7th day of treatment, the color filter paper was observed. Bacteria that can produce cyanide was detected by a color change on filter paper from yellow to orangebrown (Lorck 1948).

\section{Urease activity}

The test was performed on NFB semi-solid medium with $\mathrm{pH}$ of 6.8. The compositions of this medium were 0.5 $\mathrm{g}$ of malic acid, $0.5 \mathrm{~g}$ of $\mathrm{K}_{2} \mathrm{HPO}_{4}, 0.2 \mathrm{~g}$ of $\mathrm{MgSO}_{4} .7 \mathrm{H}_{2} \mathrm{O}$, $0.1 \mathrm{~g}$ of $\mathrm{NaCl}, 0.02 \mathrm{~g}$ of $\mathrm{CaCl}_{2} \cdot 2 \mathrm{H}_{2} \mathrm{O}, 2 \mathrm{~mL}$ of the micronutrient, $2 \mathrm{~mL}$ of Bromthymol blue, $4 \mathrm{~mL}$ of $\mathrm{Fe}$ (III) EDTA (1.64\%), $1 \mathrm{~mL}$ of vitamins solution, and $0.5 \mathrm{~g}$ of agar. The micro-nutrient solution used in this medium were conducted with the composition of $0.4 \mathrm{~g}$ of $\mathrm{CuSO}_{4} .5 \mathrm{H}_{2} \mathrm{O}$, $0.12 \mathrm{~g}$ of $\mathrm{ZnSO}_{4} .7 \mathrm{H}_{2} \mathrm{O}, 1.4 \mathrm{~g}$ of $\mathrm{H}_{3} \mathrm{BO}_{3}, 1 \mathrm{~g}$ of $\mathrm{Na}_{2} \mathrm{MoO}_{4} \cdot 2 \mathrm{H}_{2} \mathrm{O}, 1.5 \mathrm{~g}$ of $\mathrm{MnSO}_{4} \cdot \mathrm{H}_{2} \mathrm{O}$, in $1 \mathrm{~L}$ of distilled water. Vitamins solution was conducted with the composition of $10 \mathrm{mg}$ of biotin, $20 \mathrm{mg}$ of Pyridoxol HCL in $1 \mathrm{~L}$ of distilled water.

The test was performed by growing $1 \mathrm{~mL}$ of the bacterial suspension with the density of $10^{8} \mathrm{cfu} \mathrm{mL}^{-1}$ in 9 $\mathrm{mL}$ of NFB semi-solid media and incubated for 48 hours. Bacterial ability in fixing nitrogen was indicated by a color change, turned blue or dark blue, and mucus or pellicle layers on the surface of the media appeared (Baldani et al. 1986).

\section{Phosphate dissolving activity}

The test was performed using Pikovskayas Agar medium (Himedia, India). Bacterial cultures were streaked onto the surface of the medium and incubated at room temperature for 48 hours. Bacterial ability in dissolving phosphate was indicated by the clear zone around the bacterial streak (Sharma et al. 2011).

\section{Antibiotic resistance test}

24-hours-old endophytic bacteria isolates were grown in TSB medium containing $(25,50,75$, and 100$) \mu \mathrm{g} \mathrm{mL}^{-1}$ of chloramphenicol, amoxicillin and rifampicin antibiotics. If the media color turned murky then the isolates were resistant to antibiotics with the tested doses. The test was repeated 3 times (Vibhaw et al. 2017).

\section{Propagation of Meloidogyne incognita inoculum}

$M$. incognita used as materials was taken from the collection of Plant Nematology Laboratory, Department of
Plant Protection, Bogor Agricultural University. The nematode was reproduced on Tantyna F1 variety of tomato plants.

\section{Effect of filtrate culture of endophytic bacteria on nematode egg hatching}

The endophytic bacteria were grown in $100 \mathrm{~mL}$ of TSB medium and shaken for 24 hours at room temperature. After 24 hours, the suspension of the endophytic bacterial was centrifugated at $12000 \mathrm{rpm}$ for 15 minutes. Furthermore, the supernatant was filtered using $0.22 \mu \mathrm{m}$ and diameter of $25 \mathrm{~mm}$ sterile syringe filter. The filtered supernatant was used to test the ability of endophytic bacteria on egg hatching of $M$. incognita.

$M$. incognita eggs isolated from extract of the roots were sterilized by soaking in a solution containing $600 \mathrm{ppm}$ of Streptomycin sulfate for 20 minutes then washed and soaked in sterile water for 30 seconds. About $0.5 \mathrm{~mL}$ (containing 50 eggs) of suspension of $M$. incognita eggs was added into $5 \mathrm{~mL}$ of endophytic bacterial filtrate and incubated at room temperature for 48 hours. As a control, the eggs were added into $5 \mathrm{~mL}$ of sterile distilled water. After incubation, the eggs were washed with sterile water and incubated at room temperature for 14 days.

This experiment used a completely randomized design (CRD) with bacterial culture filtrate as fixed factor and each isolate was repeated 3 times. The percentage of eggs hatching indicating nematodes was out of the cuticle (the egg protectors) was recorded. Data were then analyzed using DSAASTAT program version 1.021 (Siddiqui and Shaukat 2003).

\section{Effect of filtrate culture of endophytic bacteria on mortality of $M$. incognita $\mathbf{J} 2$}

The test of the effect of bacterial filtrate on $M$. incognita was conducted by taking a $5 \mathrm{~mL}$ of bacterial culture filtrate and put into a small petri dish (diameter of 6 $\mathrm{cm}$ ) then $0.5 \mathrm{~mL}$ of the suspension of $M$. incognita juvenile (containing 100 juveniles) was added and stored at room temperature for 24 hours. This test used a completely randomized design (CRD) with bacterial culture filtrate as fixed factor and repeated 3 times. As a control, sterile water and TSB were used to prove that $M$. incognita juveniles died because of bacterial filtrate. Observations were conducted on the dead and living M. incognita. The dead $M$. incognita were characterized by straight shape and did not move after 2 hours in sterile water. The data were then analyzed using the DSAASTAT program version 1.021 (Siddiqui and Shaukat 2003).

\section{Selection of endophytic bacterial as RKN controlling agent and plant growth promoter}

The endophytic bacteria were grown in TSB medium and incubated for 48 hours. F1 Tantyna tomato variety seeds sterilized using $\mathrm{NaOCl} 1 \%$ for 1 minute and sterile distilled water were soaked in the suspension of endophytic bacteria for 12 hours. Then, tomato seeds were sown in sterile soil and after four main leaves appeared, the seeds were moved and planted in pots with a diameter of $15 \mathrm{~cm}$. Planting was conducted in a completely randomized design 
(CRD) with three replications, each test consisted of two test plants. Afterward, tomato plants were watered with 100 $\mathrm{mL}$ of the bacterial suspension with a density of $10^{8} \mathrm{cfu}$ $\mathrm{mL}^{-1}$ at the first, $2^{\text {nd }}$, and $5^{\text {th }}$ week. Watering was conducted around the base of the stem. Watering was applied in the afternoon at 16.30 .

M. incognita infestation was performed 1 month after tomato plants were moved. Total $M$. incognita infested to the plants was 500 nematodes in the infective stage (J2). Measurement of observation variables was conducted at 40 days after inoculation. Agronomic variables included height, root length, both fresh and dry weight of plants. Pathological variables included the number of nematodes per $5 \mathrm{~g}$ of roots and the number of gall at the root. Data analysis was performed at the end of the observation using analysis of variance at the 5\% level confidence. If they are significantly different then Duncan Multiple Range Test (DMRT) at 95\% level confidence was applied. The analysis was performed using DSAASTAT program version 1.021 (Munif et al. 2013).

\section{RESULTS AND DISCUSSION}

\section{Biosafety of endophytic bacteria}

Eighteen isolates of endophytic bacteria were isolated from the roots of $C$. rotundus. Among those bacteria isolates, $33.33 \%$ (6 isolates) of them caused necrosis based on hypersensitivity reaction test. Therefore, those isolates were not used in the next test. The remained isolates (12 isolates) were tested for their safety using hemolysis test. The hemolysis test showed that $16.66 \%$ of endophytic bacteria were able to produce $\beta$-hemolysis toxins, and other $5.55 \%$ were able to produce $\alpha$-hemolysis toxins. Bacteria with the indication of both negative hypersensitivity test and negative toxic hemolysis test were used in the further test. The biosafety test showed that eight isolates from plant roots of $C$. rotundus could be used in the advance test (Table 1).

\section{Phenotypic characters and endophytic bacterial Gram}

Among 8 isolates of endophytic bacteria, $100 \%$ of colonies were circular of shape. Colony size of endophytic bacteria is varied; the observations showed that $12.5 \%$ of punctiform, $37.5 \%$ of small, $37.5 \%$ of moderate and $12.5 \%$ of large size. The texture of endophytic bacterial colonies consisted of 2 types, smooth and rough. $25 \%$ were rough, and $75 \%$ were smooth. There were five colors of endophytic bacterial colonies, white $(50 \%)$, yellow $(12.5 \%)$, brown $(12.5 \%)$, red $(12.5 \%)$, and green $(12.5 \%)$. Furthermore, elevation of endophytic bacteria colonies consisted of 4 types; those were flat $(25 \%)$, raised (50\%), convex $(12.5 \%)$, umbonate $(12.5 \%)$. Based on the observations, $37.5 \%$ of endophytic bacteria were Grampositive, and $62.5 \%$ were Gram-negative (Table 2).

\section{Physiological characteristics of endophytic bacteria}

Five physiological activities were tested included proteolytic, chitinolytic, production of $\mathrm{HCN}$, urease activity and phosphate dissolving activity. The tests showed that $87.5 \%$ of bacteria had proteolytic activity, $62.5 \%$ of bacteria had activity chitinolytic, $37.5 \%$ of bacteria were able to produce $\mathrm{HCN}, 75 \%$ of bacteria had urease activity, and $87.5 \%$ of bacteria were able to dissolve phosphate (Table 3 ).

Table 1. Hypersensitive reaction and hemolysis activity of endophytic bacterial isolates originated from roots of $C$. rotundus

\begin{tabular}{lcc}
\hline Isolate code & $\begin{array}{c}\text { Hypersensitive } \\
\text { reaction }\end{array}$ & Hemolysis activity \\
\hline CRS01 & - & $\beta$ \\
CRS02 & - & - \\
CRS03 & - & - \\
CRS04 & + & $\mathrm{x}$ \\
CRS05 & - & $\beta$ \\
CRS06 & + & $\mathrm{x}$ \\
CRS07 & + & $\mathrm{x}$ \\
CRS08 & + & $\mathrm{x}$ \\
CRS09 & - & - \\
CRS10 & + & $\mathrm{x}$ \\
CRS11 & - & - \\
CRS12 & - & - \\
CRS13 & - & - \\
CRS14 & - & - \\
CRS15 & - & - \\
CRS16 & - & $\mathrm{x}$ \\
CRS17 & - & - \\
CRS18 & + & \\
\hline Note: $(+)$ endophytic bacterial isolates tested caused necrosis on \\
tobacco leaf in hypersensitivity test, $(-)$ endophytic bacterial \\
isolates tested did not cause necrosis on tobacco leaf in \\
hypersensitivity test dan had no hemolysis activity, $(\alpha)$ endophytic \\
bacterial isolates tested could produce $\alpha$-hemolysis toxins in \\
blood agar media, $(\beta)$ endophytic bacterial isolates tested could \\
produce $\beta$-hemolysis toxins in blood agar media, $(x)$ endophytic \\
bacterial isolates were not tested in hemolysis test because they \\
were detected to cause necrosis in hypersensitivity test on tobacco \\
plant. & & \\
& &
\end{tabular}

Table 2. Phenotypic and Gram characteristics of endophytic bacterial isolates originated from roots of C. rotundus

\begin{tabular}{lllllll}
\hline Isolate code & Shape & Size & Texture & Color & Elevation & Gram \\
\hline CRS02 & Circular & Small & Smooth & White & Flat & Negative \\
CRS03 & Circular & Moderate & Smooth & White & Raised & Positive \\
CRS09 & Circular & Small & Rough & Brown & Flat & Negative \\
CRS11 & Circular & Small & Smooth & White & Raised & Negative \\
CRS12 & Circular & Moderate & Smooth & Red & Umbonate & Positive \\
CRS14 & Circular & Moderate & Rough & Yellow & Raised & Negative \\
CRS16 & Circular & Large & Smooth & White & Convex & Positive \\
CRS17 & Circular & Punctiform & Smooth & Green & Raised & Negative \\
\hline
\end{tabular}




\section{Endophytic bacterial resistance to antibiotics}

In general, endophytic bacteria tested for resistance varied to three types of antibiotics. Most of the endophytic bacteria had antibiotic resistance in the concentration of 25 $\mu \mathrm{g} \mathrm{mL} L^{-1}$ up to $50 \mu \mathrm{g} \mathrm{mL}^{-1}$. Results of test on the antibiotic chloramphenicol with concentration of $25 \mu \mathrm{g} \mathrm{mL} \mathrm{mL}^{-1}, 50 \mu \mathrm{g}$ $\mathrm{mL}^{-1}, 75 \mu \mathrm{g} \mathrm{mL}^{-1}$, and $100 \mu \mathrm{g} \mathrm{mL}^{-1}$ were $100 \%, 100 \%$, $37.5 \%$ and $0 \%$, respectively. Furthermore, the results of the test on amoxicillin antibiotic with the concentration of 25 $\mu \mathrm{g} \mathrm{mL}{ }^{-1}, 50 \mu \mathrm{g} \mathrm{mL}^{-1}, 75 \mu \mathrm{g} \mathrm{mL}{ }^{-1}$, and $100 \mu \mathrm{g} \mathrm{mL}^{-1}$, respectively were $100 \%, 62.5 \%, 25 \%$ and $0 \%$. Another antibiotic tested was rifampicin, with the results in the concentration of $25 \mu \mathrm{g} \mathrm{mL}^{-1}, 50 \mu \mathrm{g} \mathrm{mL}^{-1}, 75 \mu \mathrm{g} \mathrm{mL}^{-1}$, and $100 \mu \mathrm{g} \mathrm{mL}^{-1}$ were $100 \%, 100 \%, 50 \%$, and $0 \%$, respectively (Table 4).

\section{Effectiveness of endophytic bacteria as biocontrol agents against $M$. incognita on tomato plants}

Filtrate cultures of endophytic bacterial were able to inhibit eggs hatching of $M$. incognita up to $87.33 \%$ (CRS09), 85.33\% (CRS12), 78.66\% (CRS11), 69.33\% (CRS03), 67.33\% (CRS17), 61.33\% (CRS14), 52\% (CRS16), 49.00\% (CRS02). Furthermore, the same filtrate cultures were also able to kill $M$. incognita $\mathrm{J} 2$ by $85 \%$ (CRS09), 81.67\% (CRS12), 76.66\% (CRS11), 74.33\% (CRS14), 74\% (CRS17), 72\% (CRS03), 65\% (CRS02), and $60 \%$ (CRS16) (Table 5).

Table 3. Physiological characteristics of endophytic bacterial isolates originated from roots of C. rotundus

\begin{tabular}{|c|c|c|c|c|c|}
\hline $\begin{array}{l}\text { Isolate } \\
\text { code }\end{array}$ & $\begin{array}{c}\text { Proteolytic } \\
\text { activity }\end{array}$ & $\begin{array}{c}\text { Chitinolytic } \\
\text { activity }\end{array}$ & $\begin{array}{l}\text { Production } \\
\text { of HCN }\end{array}$ & $\begin{array}{c}\text { Urease } \\
\text { activity }\end{array}$ & $\begin{array}{c}\text { Phosphate } \\
\text { dissolving } \\
\text { activity }\end{array}$ \\
\hline CRS02 & + & - & + & + & + \\
\hline CRS03 & + & - & + & + & + \\
\hline CRS09 & + & + & - & + & + \\
\hline CRS1 1 & + & + & - & + & - \\
\hline CRS12 & + & + & - & + & + \\
\hline CRS14 & - & + & - & - & + \\
\hline CRS16 & + & - & - & - & + \\
\hline CRS17 & + & + & + & + & + \\
\hline
\end{tabular}

Note: $(+)$ endophytic bacterial isolates had physiological activities and were able to produce compounds tested, $(-)$ endophytic bacterial isolates had no physiological activities and were not able to produce compounds tested

Table 4. Resistance of endophytic bacteria originated from roots of C. rotundus on chloramphenicol, amoxicillin, and rifampicin antibiotics on various concentrations.

\begin{tabular}{|c|c|c|c|c|c|c|c|c|c|c|c|c|}
\hline \multirow{2}{*}{$\begin{array}{l}\text { Isolate } \\
\text { code }\end{array}$} & \multicolumn{4}{|c|}{$\begin{array}{l}\text { Chloramphenicol } \\
\left(\mu \mathrm{g} \mathrm{mL} \mathrm{LL}^{-1}\right)\end{array}$} & \multicolumn{4}{|c|}{$\begin{array}{l}\text { Amoxicillin } \\
\left(\mu \mathrm{g} \mathrm{mL}^{-1}\right)\end{array}$} & \multicolumn{4}{|c|}{$\begin{array}{l}\text { Rifampicin } \\
\left(\mu \mathrm{g} \mathrm{mL} \mathrm{L}^{-1}\right)\end{array}$} \\
\hline & 25 & 50 & 75 & 100 & 25 & 50 & 75 & 100 & 25 & 50 & 75 & 100 \\
\hline$\overline{\mathrm{CRS} 02}$ & + & + & + & - & + & + & + & - & + & + & + & - \\
\hline CRS03 & + & + & - & - & + & + & - & - & + & + & - & - \\
\hline CRS09 & + & + & + & - & + & - & - & - & + & + & + & - \\
\hline CRS11 & + & + & + & - & + & - & - & - & + & + & - & - \\
\hline CRS12 & + & + & - & - & + & + & - & - & + & + & - & - \\
\hline CRS14 & + & + & - & - & + & - & - & - & + & + & + & - \\
\hline CRS16 & + & + & - & - & + & + & + & - & + & + & + & - \\
\hline CRS17 & + & + & - & - & + & + & - & - & + & + & - & - \\
\hline
\end{tabular}

Table 5. Effectiveness of filtrate culture of endophytic bacterial originated from roots of $C$. rotundus in inhibiting eggs hatching and killing $M$. incognita $\mathrm{J} 2$ in vitro.

\begin{tabular}{lcc}
\hline Isolate code & $\begin{array}{c}\text { Inhibition of eggs } \\
\text { hatching of } \boldsymbol{M} \text {. } \\
\text { incognita }(\%)\end{array}$ & $\begin{array}{c}\text { Mortality of } \boldsymbol{M} \text {. } \\
\text { incognita } \mathbf{J 2}(\%)\end{array}$ \\
\hline CRS02 & $49.00^{\mathrm{e}} \pm 6.24$ & $65.00^{\mathrm{de}} \pm 2.65$ \\
CRS03 & $69.33^{\mathrm{c}} \pm 1.15$ & $72.00^{\mathrm{cd}} \pm 7.94$ \\
CRS09 & $87.33^{\mathrm{a}} \pm 4.93$ & $85.00^{\mathrm{a}} \pm 4.36$ \\
CRS11 & $78.66^{\mathrm{b}} \pm 1.53$ & $76.66^{\mathrm{bc}} \pm 2.08$ \\
CRS12 & $85.33^{\mathrm{a}} \pm 2.08$ & $81.67^{\mathrm{ab}} \pm 2.08$ \\
CRS14 & $61.33^{\mathrm{d}} \pm 1.53$ & $74.33^{\mathrm{bc}} \pm 3.79$ \\
CRS16 & $52.00^{\mathrm{e}} \pm 3.00$ & $60.00^{\mathrm{e}} \pm 6.24$ \\
CRS17 & $67.33^{\mathrm{c}} \pm 3.79$ & $74.00^{\mathrm{bc}} \pm 2.65$ \\
Control & $0^{\mathrm{f}}$ & $0^{\mathrm{f}}$ \\
\hline
\end{tabular}

Note: Values followed by different superscript letters are significant at $P \leq 0.05$ over control

In general, applications of endophytic bacteria in tomato plants infested with $M$. incognita had positive effects. Plants treated with endophytic bacteria had higher plant height compared with plants untreated with the endophytic bacteria. Differences in height on the plant treated and control were $32.38 \%$ (CRS03), 32.41\% (CRS02), 39.75\% (CRS17), 44.78\% (CRS09), 46.30\% (CRS11), 46.54\% (CRS14), 48.70\% (CRS12), and 59.78\% (CRS16). In addition to plant height, all of endophytic bacteria also had a positive effect on the growth of roots. The roots of plants treated with endophytic bacteria were longer by $39.07 \%$ (CRS09), 41.16\% (CRS17), 43.26\% (CRS16), 43.54\% (CRS02), 46.90\% (CRS14), 47.03\% (CRS11), 49.20\% (CRS03), and 51.31\% (CRS12). On the other hand, all isolates were able to increase the fresh weight of the plant. The bacteria that were able to increase the fresh weight of the plants were CRS03 (10.47\%), CRS09 (12.19\%), CRS16 (20.25\%), CRS12 (22.41\%), CRS11 (23.17\%), CRS02 (25.19\%), CRS14 (29.28\%), and CRS17 (30.11\%). Furthermore, endophytic bacteria were also able to increase plant dry weight. The isolates, which effectively increased plant dry weight were CRS02 $(24.83 \%)$, CRS12 (24.95\%), CRS16 (25.92\%), CRS17 (29.70\%), and CRS14 (31.45\%).

All endophytic bacteria tested were also able to effectively reduce the number of $M$. incognita in the roots of tomato plants and reduce the number of gall caused by the infestation of $M$. incognita (Figure 1). Reduction of $M$. incognita in the roots occurred at $25.30 \%$ (CRS12), 26.51\% (CRS11), 35.54\% (CRS17), 39.16\% (CRS03), 42.77\% (CRS02), 45.18\% (CRS09), 49.40\% (CRS14), and $58.43 \%$ (CRS16). Endophytic bacteria isolates were also able to reduce the number of gall formed by $24.38 \%$ (CRS12), 29.80\% (CRS11), 34.44\% (CRS17), 37.58\% (CRS03), 38.76\% (CRS09), 38.76\% (CRS09), 39.67\% (CRS02), 41.70\% (CRS14), and 56.67\% (CRS16). 

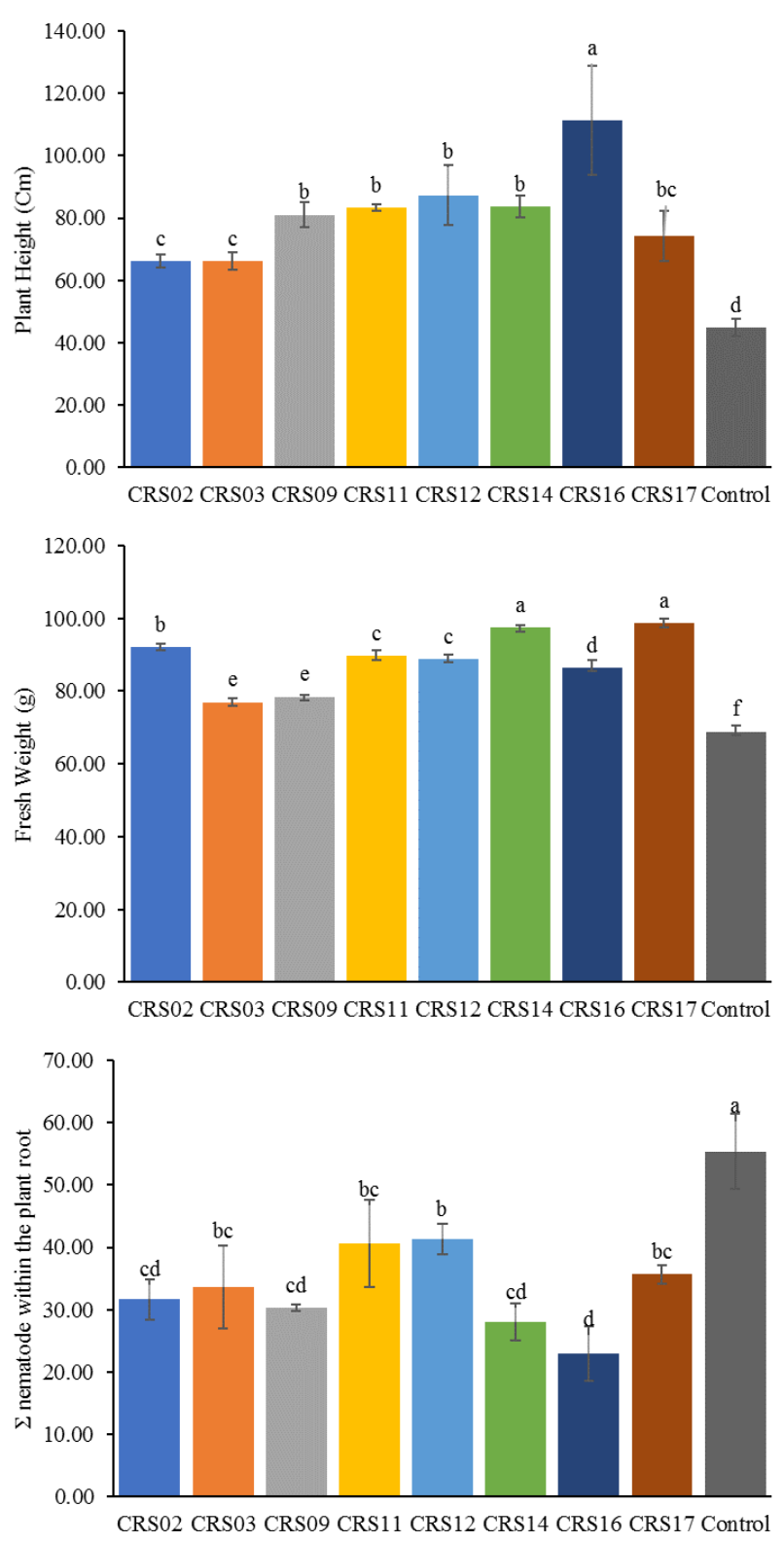
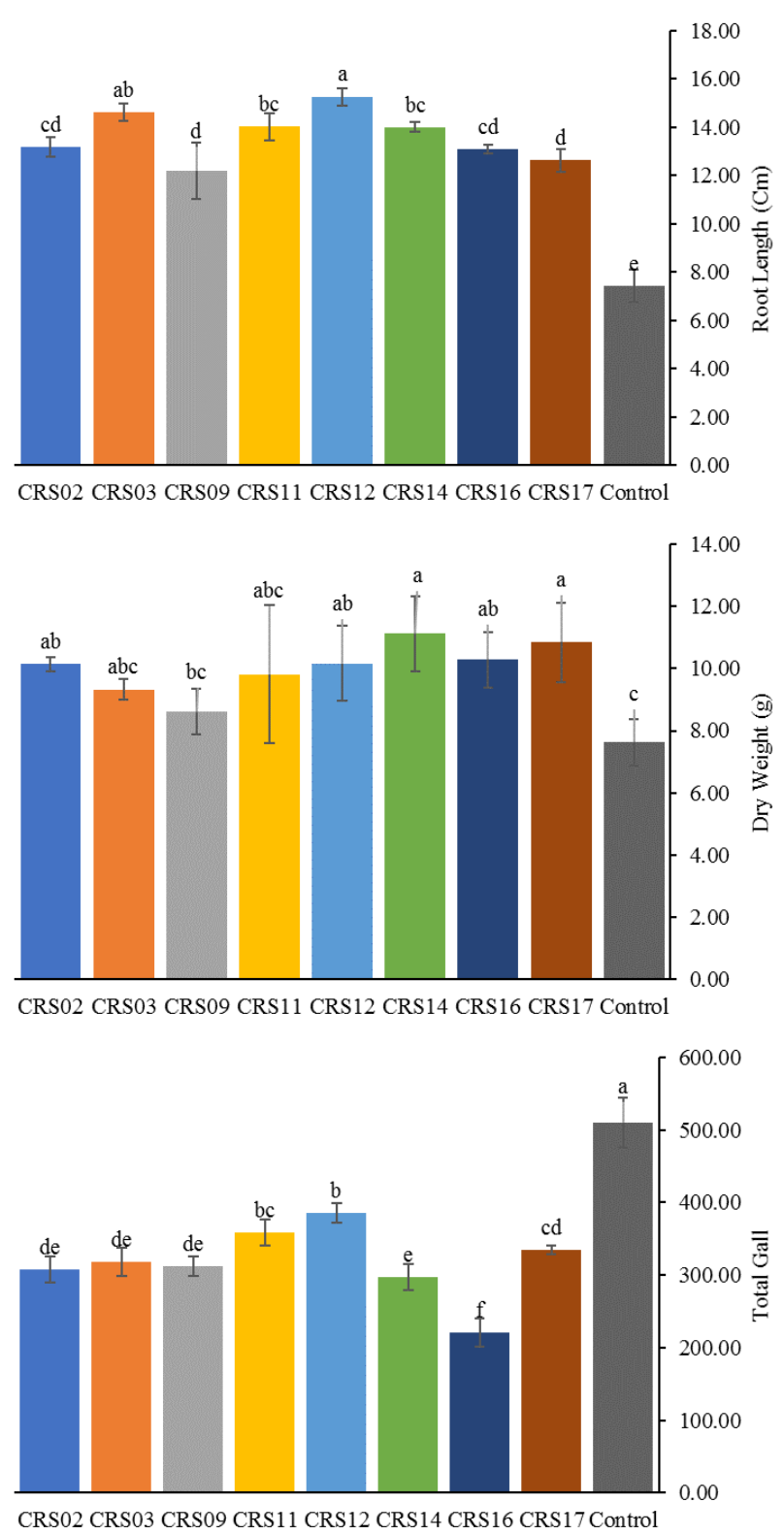

Figure 1. Growth of tomato plant infested with $M$. incognita and treated using endophytic bacteria from roots of $C$. rotundus and number of $M$. incognita and gall on each test plant. Note: values followed by different letters are significantly different from control

\section{Discussion}

The endophytic bacteria are known to be associated with almost all part of the plants, including the roots, stems, leaves, and seeds. In terms of the life cycle of endophytic bacteria, all or part of the life cycle was in the plant tissue. Not all the bacteria living within the plant tissues are beneficial to the host plant. Some endophytic bacteria are neutral, and some are pathogenic (Hardoim et al. 2015). The bacteria caused necrosis of hypersensitivity test show that these bacteria are pathogenic to plants. Hypersensitivity reactions are response of plants to pathogens infection in plant tissue that is an attempt to inhibit the growth of pathogens. Hypersensitivity reactions are influenced by hrp gene commonly found in plant pathogenic Gram-negative bacteria, such as Xanthomonas sp. groups (Zhu et al. 2000). Hypersensitivity reactions are part of the cell death program that occurs very fast and localized. The cellular membrane on the leaves of tobacco plants that have contact with pathogenic bacteria will be destroyed, undergoing drying and necrosis (Klement and Goodman 1967). Safety of bacteria as biocontrol agents is also determined from their effects on mammals. The bacteria producing hemolysis toxin cannot be used as a biocontrol agent. Hemolysis toxin is highly cytotoxic to humans granulocytes, monocytes, and lymphocytes (Herlax and Bakas 2002). 
Each bacteria can have the same or different characters from other bacteria. Phenotypic character is expression of the interaction between genes and the environment. The same bacteria grown in different environments can show different phenotypic characters. Pathogenic bacteria Ralstonia solanacearum, for example, is white turbid in Nutrient Agar media, but the colony will turn red when it is grown on media containing tetrazolium chloride antibiotics (Williamson et al. 2002). The diversity of phenotypic characters of endophytic bacteria colonies observed in this study is the result of the interaction between genes and the environment.

As biocontrol agents, endophytic bacteria can act directly or indirectly. Endophytic bacteria can directly control pathogens by producing antagonistic enzymes against pathogens. The protease and chitinase enzymes are reported to have a nematicidal effect on root-knot nematodes. HCN produced by endophytic bacteria is also reported to be able to kill nematodes. Endophytic bacteria can indirectly increase plant resistance through induced systemic resistance (ISR) mechanism. Some studies have also stated that the endophytic bacteria were capable of fixing nitrogen from the environment, and dissolving phosphorus. The abilities are closely related to the mechanisms of plant growth promoting on endophytic bacteria (Brader et al. 2014, Chebotar et al. 2015, Ma et al. 2016).

As biocontrol agents, endophytic bacteria can be applied in a vast environment. Such capabilities are indicated from how bacteria survive on the stress of antibiotics. Agricultural environment, especially in developing countries has been contaminated by a wide variety of active compounds of pesticides (De Bon et al. 2010). The bacteria which are able to survive in media containing antibiotics is expected to survive well in the environment (Myresiotis et al. 2012).

Extracellular protease enzyme produced by the endophytic bacteria has an important role in controlling some species of plant pathogens. Tian et al. (2007) reported that the production of extracellular protease by bacteria is one of the mechanisms of bacteria as control agents of rootknot nematodes Meloidogyne spp. In addition to the protease, other enzymes such as chitinase, lipase, catalase, also have a role in the antagonistic activity of endophytic bacteria against nematodes. Chitinase has an important role in nematode control because this enzyme is able to degrade the middle layer of M. Incognita eggs (Van Nguyen et al. 2007). Cronin et al. (1997) described that chitinase can inhibit eggs hatching of Globodera rostochiensis up to $90 \%$. This explains why the hatching of nematode eggs in this study may be delayed, and the cause of death of $M$. incognita $\mathrm{J} 2$ treated with filtrate cultures of endophytic bacteria. This also explains why the number of $M$. incognita in the roots and the number of gall on tomato plant roots are less than the control plants.

Several growth variables of tomato plants treated with endophytic bacterial showed better results than the control due to the activities of endophytic bacteria that are able to fix nitrogen and dissolve phosphorus. Some species of endophytic bacteria in symbiosis with plants are known to be able to fix nitrogen from the environment. Elbeltagy et al. (2001) successfully isolated the endophytic bacteria of wild rice, which the bacteria showed the ability to fix nitrogen. The bacteria are then inoculated on rice seedlings. Rice seedlings treated with endophytic nitrogen-fixing bacteria showed better growth than the control. Phosphate solvent bacteria are able to produce organic acids, such as citric, glutamate, succinate, lactate, oxalic, glyoxylic, malate, fumarate, tartrate, and $\alpha$-ketobutyric. Such organic acids have an important role in the process of dissolving phosphate that is difficult to dissolve in the medium and in the soil (Mohammadi 2012). Manzoor et al. (2017) reported that some phosphate solvent bacteria are able to promote the growth of corn plants.

This study provides new information that endophytic bacteria originated from roots of $C$. rotundus have potential as a biocontrol agent. Endophytic bacteria are able to reduce the number of $M$. incognita in the roots of plants and are able to reduce the number of gall on the roots of tomato plants infested with $M$. incognita. Each isolate had activities of proteolytic, chitinolytic, and was able to produce $\mathrm{HCN}$, fix nitrogen and dissolve phosphate. In general, CRS16 isolate has the best performance and stable as a biocontrol agent of $M$. incognita on tomato plants.

\section{REFERENCES}

Baldani J, Baldani V, Seldin L, Döbereiner J. 1986. Characterization of Herbaspirillum seropedicae gen. nov., sp. nov., a root-associated nitrogen-fixing bacterium. Int J Syst Evol Microbiol 36 (1): 86-93.

Beveridge TJ. 2001. Use of the Gram stain in microbiology. Biotech Histochem 76 (3): 111-118.

Brader G, Compant S, Mitter B, Trognitz F, Sessitsch A. 2014. Metabolic potential of endophytic bacteria. Curr Opin Biotechnol 27: 30-37.

Chebotar V, Malfanova N, Shcherbakov A, Ahtemova G, Borisov A, Lugtenberg B, Tikhonovich I. 2015. Endophytic bacteria in microbial preparations that improve plant development (review). Appl Biochem Microbiol 51 (3): 271-277.

Cronin D, Moënne-Loccoz Y, Dunne C, O'gara F. 1997. Inhibition of egg hatch of the potato cyst nematode Globodera rostochiensis by chitinase-producing bacteria. Eur J Plant Pathol 103 (5): 433-440.

De Bon H, Parrot L, Moustier P. 2010. Sustainable urban agriculture in developing countries a review. Agron Sustain Dev 30 (1): 21-32.

Elbeltagy A, Nishioka K, Sato T, Suzuki H, Ye B, Hamada T, Isawa T, Mitsui H, Minamisawa K. 2001. Endophytic colonization and in planta nitrogen fixation by a Herbaspirillum sp. isolated from wild rice species. Appl Environ Microbiol 67 (11): 5285-5293.

Hackenberg C, Muehlkchen A, Forge T, Vrain T. 2000. Pseudomonas chlororaphis strain Sm3, bacterial antagonist of Pratylenchus penetrans. J Nematol 32 (2): 183-189.

Hallmann J, Berg, G, Schulz, B. 2006. Isolation procedures for endophytic microorganisms. In: Schulz BJE, Boyle CJC, Sieber TN (eds). Microbial Root Endophytes. Springer, Germany.

Hardoim PR, Van Overbeek LS, Berg G, Pirttilä AM, Compant S, Campisano A, Döring M, Sessitsch A. 2015. The hidden world within plants: ecological and evolutionary considerations for defining functioning of microbial endophytes. Microbiol Mol Biol Rev 79 (3): 293-320.

Herlax V, Bakas LS. 2002. Aplicaciones terapéuticas de toxinas líticas formadoras de poros: potencialidades de ahemolisina de Escherichia coli. Medicina 62: 66-72.

Klement Z, Goodman R. 1967. The hypersensitive reaction to infection by bacterial plant pathogens. Ann Rev Phytopathol 5 (1): 17-44

Krechel A, Faupel A, Hallmann J, Ulrich A, Berg G. 2002. Potatoassociated bacteria and their antagonistic potential towards plantpathogenic fungi and the plant-parasitic nematode Meloidogyne 
incognita (Kofoid \& White) Chitwood. Can J Microbiol 48 (9): 772786.

Kuddus M, Ahmad I. 2013. Isolation of novel chitinolytic bacteria and production optimization of extracellular chitinase. Genet Eng Biotechnol 11 (1): 39-46.

Lorck H. 1948. Production of hydrocyanic acid by bacteria. Physiologia Plantarum 1 (2): 142-146.

Ma Y, Rajkumar M, Zhang C, Freitas H. 2016. Beneficial role of bacterial endophytes in heavy metal phytoremediation. J Environ Manage 174: 14-25.

Manzoor M, Abbasi MK, Sultan T. 2017. Isolation of phosphate solubilizing bacteria from maize rhizosphere and their potential for rock phosphate solubilization-mineralization and plant growth promotion. Geomicrobiol J 34 (1): 81-95.

Mekete T, Hallmann J, Kiewnick S, Sikora R. 2009. Endophytic bacteria from Ethiopian coffee plants and their potential to antagonise Meloidogyne incognita. Nematology 11 (1): 117-127.

Moens M, Perry RN, Starr JL. 2009. Meloidogyne species-a diverse group of novel and important plant parasites. In: Perry RN, Moens M, Starr JL (eds). Root-Knot Nematodes. CABI, United Kingdom.

Mohammadi K. 2012. Phosphorus solubilizing bacteria: occurrence, mechanisms and their role in crop production. Resour Environ 2 (1): 80-85.

Mohanty SR, Dubey G, Kollah B. 2017. Endophytes of Jatropha curcas promote growth of maize. Rhizosphere 3: 20-28.

Munif A, Hallmann J, Sikora RA. 2013. The influence of endophytic bacteria on Meloidogyne incognita infection and tomato plant growth. J ISSAAS 19 (2): 68-74.

Muthamia J, Ravichandra N. 2012. Effect of root-knot nematode (Meloidogyne incognita), Fusarium oxysporum f. sp. lycopersici and Ralstonia solanacearum wilt complex on uptake of essential minerals (NPK) in tomato. Mysore J Agri Sci 46 (1): 186-188.

Myresiotis CK, Vryzas Z, Papadopoulou-Mourkidou E. 2012 Biodegradation of soil-applied pesticides by selected strains of plant growth-promoting rhizobacteria (PGPR) and their effects on bacterial growth. Biodegradation 23 (2): 297-310.

Pieterse CM, Zamioudis C, Berendsen RL, Weller DM, Van Wees SC, Bakker PA. 2014. Induced systemic resistance by beneficial microbes. Ann Rev Phytopathol 52: 347-375.

Sharma S, Kumar V, Tripathi RB. 2011. Isolation of phosphate solubilizing microorganism (PSMs) from soil. J Microbiol Biotechnol Res 1 (2): 90-95.

Siddiqui IA, Shaukat SS. 2003. Suppression of root-knot disease by Pseudomonas fluorescens CHA0 in tomato: importance of bacterial secondary metabolite, 2, 4-diacetylpholoroglucinol. Soil Biol Biochem 35 (12): 1615-1623.

Sokol PA, Ohman DE, Iglewski BH. 1979. A more sensitive plate assay for detection of protease production by Pseudomonas aeruginosa. J Clin Microbiol 9 (4): 538-540.

Tian B, Yang J, Zhang K-Q. 2007. Bacteria used in the biological control of plant-parasitic nematodes: populations, mechanisms of action, and future prospects. FEMS Microbiol Ecol 61 (2): 197-213.

Tille P. 2015. Bailey \& Scott's Diagnostic Microbiology. Elsevier, Amsterdam.

Van Nguyen N, Kim Y-J, Oh K-T, Jung W-J, Park R-D. 2007. The role of chitinase from Lecanicillium antillanum B-3 in parasitism to rootknot nematode Meloidogyne incognita eggs. Biocontrol Sci Technol 17 (10): 1047-1058.

Vibhaw V, Pranay K, Pratihast K, Mishra BB, Padmadeo S. 2017. Antibiotic resistance bacteria associated in waters discharges of a hospital in Patna. J Microbiol Biotechnol Res 7 (1): 9-13.

Williamson L, Nakaho K, Hudelson B, Allen C. 2002. Ralstonia solanacearum race 3 , biovar 2 strains isolated from geranium are pathogenic on potato. Plant Disease 86 (9): 987-991.

Zhu W, MaGbanua MM, White FF. 2000. Identification of Two novel hrp-associated genes in the hrp gene cluster of Xanthomonas oryzae pv. oryzae. J Bacteriol 182 (7): 1844-1853. 